Dhaka Univ. J. Biol. Sci. 28(1): 121-129, 2019 (January)

\title{
EFFECTS OF VERMICOMPOST AND COMPOST ON SOIL PROPERTIES AND GROWTH AND YIELD OF KALMI (IPOMOEA AQUATICA FORSK.) IN MIXED SOIL
}

\author{
Afroja Nasrin, Sayma Khanom* and Shahid AkHTar Hossain \\ Department of Soil, Water and Environment, University of Dhaka, Dhaka-1000, Bangladesh
}

Key words: vermicompost, compost, Ipomoea aquatica, mixed soil

\begin{abstract}
An incubation study was conducted to find out the best mixing ratio of acid and calcareous soil (maintaining $70 \%$ moisture) for pot experiment. Depending on various physico-chemical properties mixed soil $1: 1$ (i.e. acid : calcareous) was selected for pot experiment. The pot experiment was carried out to observe the effects of vermicompost and compost on soil properties and growth and yield of Kalmi (Ipomoea aquatica Forsk.). This experiment included seven treatments with three replications including control. Treatment variables were $\mathrm{T}_{0}$ (control), $\mathrm{T}_{1}$ (4t/ha vermicompost), $\mathrm{T}_{2}$ ( $8 \mathrm{t} / \mathrm{ha}$ vermicompost), $\mathrm{T}_{3}$ (12 $\mathrm{t} / \mathrm{ha}$ vermicompost), $\mathrm{T}_{4}\left(4 \mathrm{t} /\right.$ ha compost), $\mathrm{T}_{5}$ ( $8 \mathrm{t} /$ ha compost) and $\mathrm{T}_{6}(12 \mathrm{t}$ /ha compost). All the treatments had significant positive effects over control on growth and yield of kalmi. The highest growth and yield were recorded with $T_{3}$ (12 t/ha vermicompost) treatment. In case of, macro and micronutrient uptake treatment $\mathrm{T}_{3}$ (12 $\mathrm{t}$ /ha vermicompost) performed best followed by $\mathrm{T}_{6}(12 \mathrm{t} /$ ha compost) over $\mathrm{T}_{0}$ (control). However, in post-harvest soil except soil reaction $(\mathrm{pH})$; electrical conductivity (EC), organic carbon (OC), available $\mathrm{N}, \mathrm{P}, \mathrm{K}, \mathrm{S}, \mathrm{Ca}, \mathrm{Mg}, \mathrm{Na}, \mathrm{Fe}$ and Zn significantly increased for $T_{3}\left(12 t a^{-1}\right.$ vermicompost) than $T_{1}, T_{2}, T_{4}, T_{5}, T_{6}$ and $\mathrm{T}_{0}$.
\end{abstract}

\section{Introduction}

Bangladesh is a developing country where agriculture plays a vital role. About $85 \%$ of the total population in the country depends on agriculture directly or indirectly for their livelihood. Most of the soils of Bangladesh are low to medium acidic in nature; due to predominance of high rainfall areas and leaching of basic cations ${ }^{(1)}$. Acid soil possesses high concentration of $\mathrm{Al}^{3+}, \mathrm{Fe}^{3+}, \mathrm{Mn}^{2+}$ and low concentration of $\mathrm{P}$, low availability of bases and in calcareous soil there is abundance of $\mathrm{Ca}, \mathrm{Mg}$ but lack of $\mathrm{Fe}, \mathrm{Mn}, \mathrm{Zn}, \mathrm{B}$ and phosphate and nitrate ${ }^{(2)}$. Mitigation measures to reclaim acid and calcareous soils are very much expensive and intricate to local farmers. So, mixing of these two kinds of soils to get a reasonable soil $\mathrm{pH}$ which is finally termed mixed soil may give adequate supply of the nutrient elements.

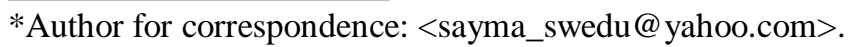


Moreover, the soils of Bangladesh are basically very low in organic matter, deficient in plant nutrients, especially nitrogen and phosphorus. Due to poor management practices and unbalanced use of chemical fertilizers, organic matter content is getting reduced day by day that ultimately reduces microbial activity and causes macro and micro nutrient deficiencies(3). Therefore, organic farming systems with the aid of various nutrients of biological origin like vermicompost and compost are thought to be the answer to sustain soil fertility and crop productivity.

Vermicompost is a potential input and nutritive organic fertilizer rich in humus, macro and micro nutrients, growth hormones (auxines, gibberlins and cytokinins) and beneficial for soil microbes. It is an excellent soil amendment and conditioner ${ }^{(4)}$. With the continued application of vermicompost the 'organic nitrogen' and other nutrients tends to be released at a constant rate from the accumulated 'humus'. The net overall efficiency of NPK over a period of years is considerably greater than that of chemical fertilizers. It is a new solution in sustainable agriculture that not only promotes excellent growth of crops but also protects them from pests and diseases ${ }^{(5)}$. On the other hand, compost is an aerobically decomposed product of organic wastes that contains beneficial soil microbes which help in soil regeneration. It supplies balanced nutrients and improves the physical and chemical properties of the soil. Matured composts are stable and have pleasant smell, but if the composting process is ended prematurely, the resulting immatured compost may have negative effects on soils and plants(6). The current research was undertaken to examine effects of vermicompost and compost on the growth and yield of kalmi (Ipomoea aquaticaForsk.) grown in mixed soil and also to determine changes in soil properties due to application of vermicompost and compost.

\section{Materials and Methods}

The study area for sample collection was chosen depending on high and low $\mathrm{pH}$ of soil. For low $\mathrm{pH}$, acid soils were collected from Binnapara, a village of Chehelgazi Union of Dinajpur Sadar Upazilla in Dinajpur district. For high $\mathrm{pH}$, calcareous soils were collected from West Gongabordi, a village of Krishnanagar union of Faridpur Sadar Upazilla in Faridpur district.

The soils were collected at $0-15 \mathrm{~cm}$ depth from both sampling sites. The collected soil samples were air-dried for 3 days. Visible roots and debris were removed. After airdrying, the larger aggregates were broken by a wooden hammer. Then an incubation study was run by mixing acid and calcareous soils at different ratios like $1: 1,2: 1,5: 3,7$ $: 1,0: 4$, and $4: 0$ maintaining 70\% moisture. Depending on physico-chemical properties, 1:1 ratio was selected for pot experiment (Table 1). Approximately $500 \mathrm{~g}$ of each sample was taken for physico-chemical analysis which was screened to pass through a $2 \mathrm{~mm}$ stainless steel sieve. 


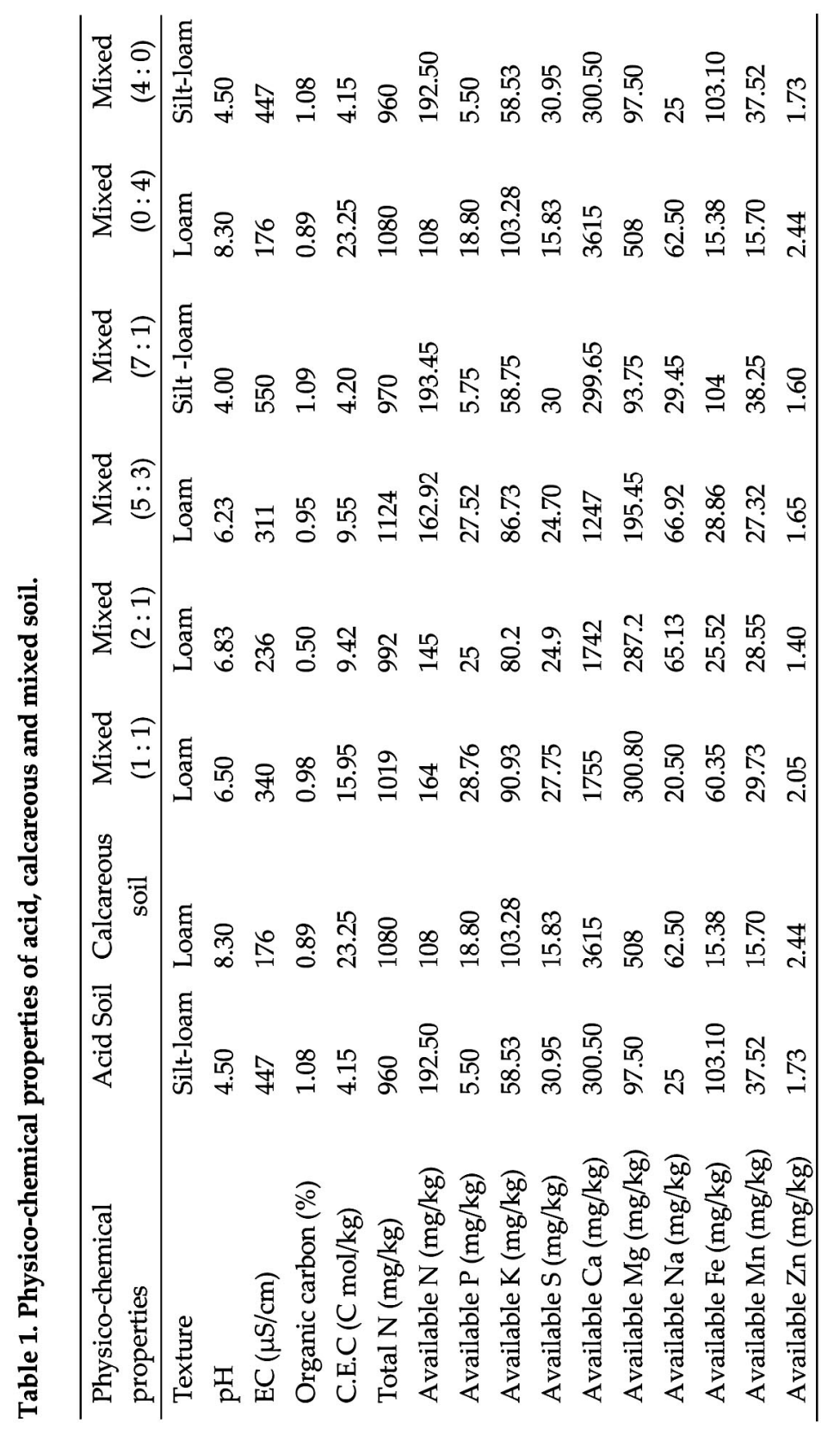


Vermicompost and compost were used as organic fertilizers. Vermicompost was collected from a farm situated in Keraniganj and compost was collected from a farm house at Sreepur area in Gazipur. Collected vermicompost and compost were passed through a $0.5 \mathrm{~mm}$ stainless steel sieve and different physical, chemical and physicochemical properties were determined following standard method as described by Jackson(7) (Table 2).

Table 2. Properties of Vermicompost and Compost.

\begin{tabular}{lcc}
\hline Properties & Vermicompost & Compost \\
\hline Colour & Dark grey to black & Dark grey \\
Physical condition & Non- granular form & Non- granular form \\
Odour & Absence of foul odour & Presence of foul odour \\
pH & 8.50 & 8.16 \\
EC $(\mathrm{dS} / \mathrm{m})$ & 5.63 & 3.47 \\
OC $(\%)$ & 24.54 & 19.40 \\
Total N $(\%)$ & 2.40 & 1.69 \\
Total P $(\%)$ & 0.93 & 0.81 \\
Total K $(\%)$ & 0.54 & 0.34 \\
Total S $(\%)$ & 0.25 & 0.12 \\
Total Ca $(\%)$ & 1.90 & 1.45 \\
Total Mg $(\%)$ & 0.92 & 0.79 \\
Total Na $(\%)$ & 1.15 & 1.06 \\
Total Fe $(\%)$ & 0.16 & 0.12 \\
Total Mn $(\mathrm{mg} / \mathrm{kg})$ & 220 & 140 \\
Total Zn $(\mathrm{mg} / \mathrm{kg})$ & 110 & 90 \\
\hline
\end{tabular}

The experiment was laid out in Completely Randomized Design (CRD) with three replications. To set up the experiment all plastic pots were filled up with $3 \mathrm{~kg}$ of air-dried mixed soil $(1: 1)$. Before seeding, recommended doses of fertilizers (RDF) were mixed according to fertilizer recommendation guide ${ }^{(8)}$.

Seeds of Kalmi (Ipomoea aquatica Forsk.)were collected from BADC and aboutten seeds were sown in each pot on June, 2016. After 3-4 days of germination, thinning was done and four plants were allowed to grow. Cultural operations were done when necessary. After 42 days, kalmi plants were collected from each pot and plant height and fresh weight were taken. After harvesting of plants, soils from each pot were collected using a hoe and processed as described earlier and various physico-chemical properties were analyzed using standard procedure as described by Jackson ${ }^{(7)}$. 


\section{Results and Discussions}

Effects on growth parameters and yield: Application of different rates of vermicompost and compost showed significant positive effects on plant height, fresh weight and yieldof kalmi (Table 3).

Growth parameters: Plant height $(\mathrm{PH})$ is an important morphological character. The highest plant height $(64 \mathrm{~cm})$ was found with $\mathrm{T}_{3}(12 \mathrm{t} /$ ha vermicompost) treatment, which was $28 \%$ higher over $\mathrm{T}_{0}$ (control) and the second highest plant height $(62.7 \mathrm{~cm})$ was found with treatment $\mathrm{T}_{6}$ (12 tha compost) which was $25.34 \%$ higher over $\mathrm{T}_{0}$ (control). Similarly, the maximum plant fresh weight (35.09 t/ha) was recorded with $\mathrm{T}_{3}$ (12 t/ha vermicompost) which was $60.74 \%$ higher over control (Table 3 ).

Table 3. Growth and yield of kalmi in response to different treatments.

\begin{tabular}{lccc}
\hline Treatment & $\begin{array}{c}\text { Plant height } \\
(\mathrm{cm})\end{array}$ & $\begin{array}{c}\text { Fresh weight } \\
(\mathrm{t} / \text { ha })\end{array}$ & $\begin{array}{c}\text { Yield } \\
(\mathrm{t} / \text { ha })\end{array}$ \\
\hline $\mathrm{T}_{0}$ (Control) & 50.0 & 21.83 & 2.98 \\
$\mathrm{~T}_{1}(4 \mathrm{t}$ /ha vermicompost $)$ & 52.7 & 29.15 & 3.87 \\
$\mathrm{~T}_{2}(8 \mathrm{t}$ /ha vermicompost $)$ & 58.8 & 31.49 & 4.46 \\
$\mathrm{~T}_{3}(12 \mathrm{t}$ /ha vermicompost $)$ & 64.0 & 35.09 & 5.13 \\
$\mathrm{~T}_{4}(4 \mathrm{t}$ /ha compost) & 50.5 & 27.91 & 3.79 \\
$\mathrm{~T}_{5}(8 \mathrm{t}$ /ha compost) & 55.0 & 30.33 & 4.29 \\
$\mathrm{~T}_{6}(12 \mathrm{t}$ /ha compost) & 62.7 & 33.19 & 5.02 \\
LSD at $5 \%$ & 4.12 & 4.37 & 1.07 \\
\hline
\end{tabular}

Yield: Statistically significant positive effects of all the treatments on yield of kalmi were found in the experiment. The maximum yield of kalmi ( $5.13 \mathrm{t} / \mathrm{ha}$ ) was obtained in $\mathrm{T}_{3}$ (12 $\mathrm{t}$ /ha vermicompost) which was $72.15 \%$ higher over control (Table 3). Yield of kalmi ranked in the order of $\mathrm{T}_{3}>\mathrm{T}_{6}>\mathrm{T}_{2}>\mathrm{T}_{5}>\mathrm{T}_{1}>\mathrm{T}_{4}>\mathrm{T}_{0}$. It appeared that maximum plant height, green weight and dry weight were attained with the highest dose of vermicompost application which was similar to the result reported by Atarzadeh et al.(9) and Karmakar et al. ${ }^{(10)}$.

Effects on nutrient uptake in plant: Application of different rates of vermicompost and compost showed significant positive effects on macro and micronutrient uptake of kalmi (Table 4).

Macronutrient uptake: Application of different treatments showed statistically significant positive effects on macronutrient uptake of kalmi. The highest amount of $\mathrm{N}$ uptake (84.65 $\left.\mathrm{kg} \mathrm{ha}^{-1}\right), \mathrm{P}$ uptake (41.78 $\mathrm{kg}$ ha), K uptake (218.10 kg ha), S uptake (34.40 $\mathrm{kg} / \mathrm{ha})$, Ca uptake (90.29 $\mathrm{kg} / \mathrm{ha}$ ) and $\mathrm{Mg}$ uptake (18.47 $\mathrm{kg}$ ha) was found with treatment $\mathrm{T}_{3}$ (12 tha vermicompost) which were 82.09, 138.47, 400.34, 209.1, 103.35 and 377.3\%, respectively higher over control. Similarly, the second highest amount of $\mathrm{N}$ uptake (81.83 
$\mathrm{kg}$ ha), P uptake (38.43 kg/ha), K uptake (190.51 kg/ha), S uptake (30.62 kg/ha), Ca uptake (85.80 kg ha) and $\mathrm{Mg}$ uptake (15.13 kg/ha) was found with $\mathrm{T}_{6}$ (12 t/ha compost) which were $76.02,119.35,337.05,175.1,93.24$ and $290.96 \%$, respectively higher over $\mathrm{T}_{0}$ (Table 4 ) which was similar to the findings of Akhter et al.(11).

Table 4. Uptake of macro and micronutrients by kalmi in different treatments.

\begin{tabular}{lccccccccccc}
\hline \multirow{2}{*}{ Treatment } & \multicolumn{1}{c}{ Macro and Micronutrient uptake (kg/ha) } \\
\cline { 2 - 11 } & $\mathrm{N}$ & $\mathrm{P}$ & $\mathrm{K}$ & $\mathrm{S}$ & $\mathrm{Ca}$ & $\mathrm{Mg}$ & $\mathrm{Na}$ & $\mathrm{Fe}$ & $\mathrm{Mn}$ & $\mathrm{Zn}$ \\
\hline $\mathrm{T}_{0}$ (Control) & 46.49 & 17.52 & 43.59 & 11.13 & 44.40 & 3.87 & 30.99 & 1.48 & 0.156 & 0.180 \\
$\mathrm{~T}_{1}$ (4 t/ha vermicompost) & 61.15 & 25.15 & 94.83 & 18.59 & 60.73 & 8.13 & 46.03 & 2.32 & 0.215 & 0.290 \\
$\mathrm{~T}_{2}$ (8 t/ha vermicompost) & 72.25 & 32.21 & 132.28 & 25.50 & 74.93 & 12.49 & 105.70 & 3.39 & 0.262 & 0.389 \\
$\mathrm{~T}_{3}$ (12 t/ha vermicompost) & 84.65 & 41.78 & 218.10 & 34.40 & 90.29 & 18.47 & 151.85 & 4.77 & 0.354 & 0.491 \\
$\mathrm{~T}_{4}$ (4 t/ha compost) & 59.50 & 23.50 & 86.47 & 16.30 & 57.47 & 6.82 & 42.36 & 2.04 & 0.203 & 0.277 \\
$\mathrm{~T}_{5}$ (8 t/ha compost) & 68.64 & 29.63 & 117.72 & 23.60 & 69.50 & 10.55 & 100.20 & 3.01 & 0.250 & 0.351 \\
$\mathrm{~T}_{6}$ (12 t/ha compost) & 81.83 & 38.43 & 190.51 & 30.62 & 85.80 & 15.13 & 141.53 & 4.23 & 0.317 & 0.450 \\
LSD at 5\% & 0.749 & 0.814 & 0.574 & 0.287 & 0.206 & 0.226 & 0.237 & 0.049 & 0.016 & 0.036 \\
\hline
\end{tabular}

Micronutrient uptake: The highest uptake of $\mathrm{Na}(151.85 \mathrm{~kg} / \mathrm{ha}), \mathrm{Fe}(4.77 \mathrm{~kg} / \mathrm{ha}), \mathrm{Mn}$ $(0.354 \mathrm{~kg} / \mathrm{ha})$ and $\mathrm{Zn}(0.491 \mathrm{~kg} / \mathrm{ha})$ was recorded for treatment $\mathrm{T}_{3}(12 \mathrm{t} /$ ha vermicompost) followed by $\mathrm{T}_{6}(12 \mathrm{t}$ /ha compost) which were $390,222.3,126.9$ and $172.8 \%$, respectively higher over control (Table. 4).

Effect on physico-chemical properties of post harvested soil samples: Application of different treatments of vermicompost and compost showed significant positive effects on physicochemical changes of the post-harvest soil.

In different treatments,soil $\mathrm{pH}$ of post-harvest soil samples significantly decreased from controlexcept $\mathrm{T}_{4}$ (4t/ha compost). The minimum soil $\mathrm{pH}$ (7.42) was recorded in $\mathrm{T}_{3}$ (12 tha vermicompost) followed by $\mathrm{T}_{6}(12 \mathrm{t}$ /ha compost) and the maximum soil $\mathrm{pH}$ (7.69) was obtained in control (Table 5) which was similar to the findings of Atiyeh et al. ${ }^{(12)}$ and Butler et al.(13). Electrical conductivity (EC) of post-harvest soil samples significantly increased with all treatments over control. The highest EC $(290 \mu \mathrm{S} / \mathrm{cm})$ was observed in treatment $T_{3}$ (12 $t$ /ha vermicompost) followed by $T_{6}(12 t /$ ha compost) over control (Table $5)$ which was similar to the results of Azarmi et al.(14). The maximum organic carbon (OC) $(1.30 \%)$ was found for treatment $\mathrm{T}_{3}$ (12 tha vermicompost) followed by $\mathrm{T}_{6}$ (12 tha compost) and the minimum organic carbon (OC) (0.95\%) was obtained with control (Table 5). Similar results were obtained by Whalen et al. ${ }^{(15)}$.

The highest available $\mathrm{N}$ content $(138 \mathrm{mg} / \mathrm{kg}), \mathrm{P}$ content $(15.45 \mathrm{mg} / \mathrm{kg}), \mathrm{K}$ content (79.85 mg/kg), S content (28.50 mg/kg), Ca content $(2043 \mathrm{mg} / \mathrm{kg}$ ) and $\mathrm{Mg}$ content (335.3 $\mathrm{mg} / \mathrm{kg}$ ) were recorded with $\mathrm{T}_{3}$ (12 $\mathrm{t} /$ ha vermicompost) followed by $\mathrm{T}_{6}$ (12 $\mathrm{t} /$ ha compost) over control (Table 5). Similar results were reported by Renato et al. ${ }^{(16)}$ and $\operatorname{Nardi}^{(17)}$. 


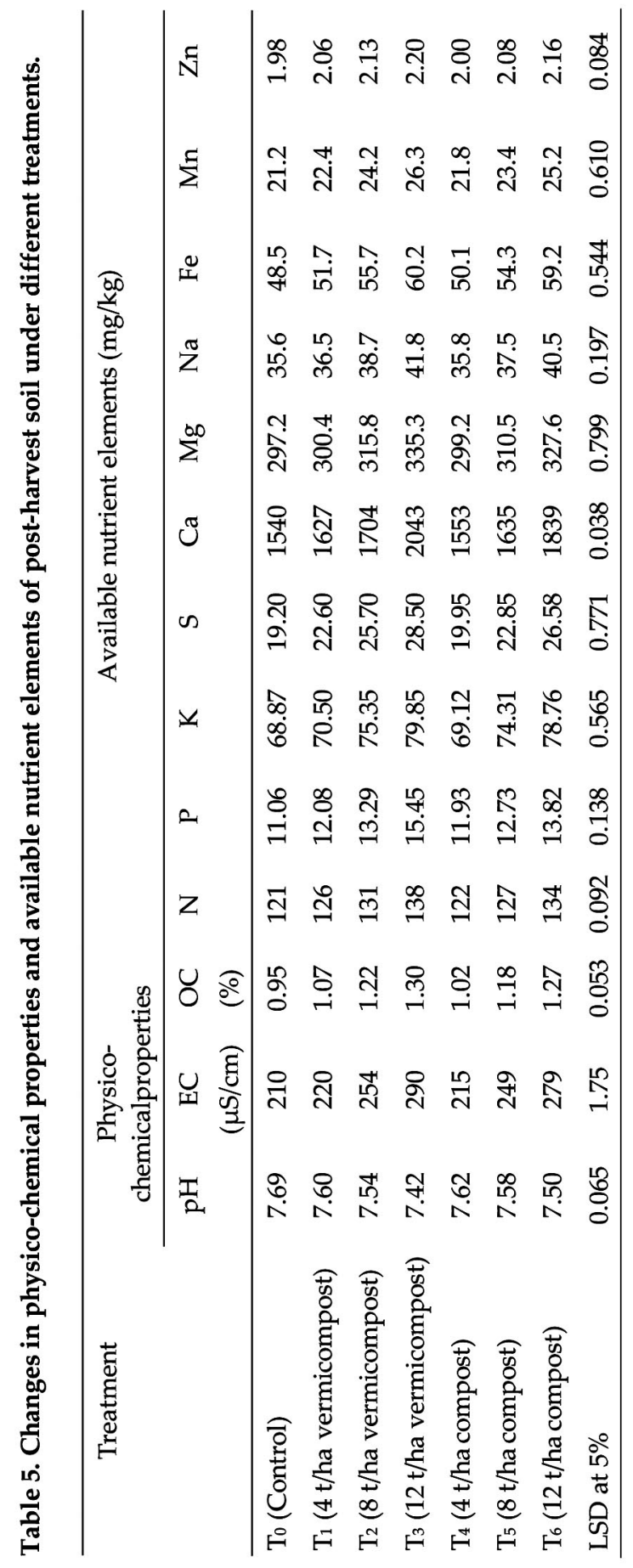


Similarly, the highest available $\mathrm{Na}$ content $(41.8 \mathrm{mg} / \mathrm{kg})$, Fe content $(60.2 \mathrm{mg} / \mathrm{kg}), \mathrm{Mn}$ content $\left(26.3 \mathrm{mg} / \mathrm{kg}\right.$ ) and $\mathrm{Zn}$ content $(2.20 \mathrm{mg} / \mathrm{kg})$ were found with $\mathrm{T}_{3}$ (12 t/ha vermicompost) followed by $\mathrm{T}_{6}$ (12 $\mathrm{t} / \mathrm{ha}$ compost) and the lowest available Na content (35.6 mg/kg), Fe content $(48.5 \mathrm{mg} / \mathrm{kg}), \mathrm{Mn}$ content $(21.2 \mathrm{mg} / \mathrm{kg})$ and $\mathrm{Zn}$ content (1.98 $\mathrm{mg} / \mathrm{kg}$ ) were found with control (Table 5) which was similar to the findings ofChoudhary and Jat ${ }^{(18)}$.

From the study it is revealed that due to mixing of acid and calcareous soil at $1: 1$ ratio, soil $\mathrm{pH}$ became neutral and other physico-chemical properties were at optimum level. All the treatments had significant positive effects over control in respect of growth parameters and yield of kalmi. The highest plant height $(64 \mathrm{~cm})$, fresh weight $(35.09 \mathrm{t} / \mathrm{ha})$ and yield ( $5.13 \mathrm{t} / \mathrm{ha}$ ) were recorded with treatment $\mathrm{T}_{3}(12 \mathrm{t} / \mathrm{ha}$ vermicompost) followed by $\mathrm{T}_{6}$ (12 t/ha compost) over control. Themaximum macro and micro nutrient uptake were obtained for $\mathrm{T}_{3}$ (12 $\mathrm{t} /$ ha vermicompost) treatment. Application of different rates of treatments showed statistically significant positive effects on physico-chemical properties of post-harvest soil. Except soil reaction $(\mathrm{pH})$; electrical conductivity (EC), organic carbon (OC), available $\mathrm{N}, \mathrm{P}, \mathrm{K}, \mathrm{S}, \mathrm{Ca}, \mathrm{Mg}, \mathrm{Na}, \mathrm{Fe}, \mathrm{Mn}$ and $\mathrm{Zn}$ increased for treatment $\mathrm{T}_{3}$ (12 tha vermicompost) over control. Considering all the points, it is found that vermicompost appeared to be the most efficient organic fertilizer to increase growth, yield and make changes in soil properties.

\section{Acknowledgement}

This work is a part of MS Thesis financed by Ministry of Science and Technology, Govt. of the People's Republic of Bangladesh.

\section{References}

1. Solaiman ASM 2014. Land degradation in Bangladesh: A challenge to face food security. Department of Agroforestry and Environment, BSMRAU, Gazipur.

2. Hassan 2012. Soil Science.Institute of African Research and Studies, Cairo University.

3. Sikder T, JC Joardar and SMI Huq 2007. Sewage sludge as soil ameliorator. Bangladesh Environ. 3(1): 63-73.

4. Ali MZ 2007. Effects of Vermicompost and Chemical Fertilizers on Growth, Yield and Nutrient Contents of Mungbean (Vigna radiate L.).An MS. Thesis. Dept. of Soil Science, Bangladesh Agricultural University, Mymensingh.

5. AlbanellE, J Plaixats and T Cabrero1988. Chemical changes during vermicomposting (Eisenia Andrei) of sheep manure mixed with cotton industrial wastes. Biol. Fertil Soil. 6: 266-269.

6. Naidu Y, S Meon, J Kadir and Y Siddiqui 2010. Microbial Starter for the Enhancement of Biological Activity of Compost Tea. Int. J. Agric Biol. 12(1): 51-56.

7. Jackson ML 1962. Soil Chemical Analysis.Prentice Hall of India Pvt. Ltd. New Delhi. pp.215224. 
8. BARC (Bangladesh Agriculture Research Council) 2012. Fertilizer Recommendation Guide.Soils Publication No. 45. ISBN: 978-984-500-000-0. pp. 7-35.

9. Atarzadeh SH, M Mojaddam and TS Nejad 2013. The interactive effects of humic acid application and several of nitrogen fertilizer on remobilization star wheat. Int. J. Biol. Sci. 3(8): 116-123.

10. Karmakar S, M Adhikary, A Gangopadhyay and K Brahmachari 2015. Impact of Vermicomposting in Agricultural Waste Management vis-à-vis Soil Health Care. J. Environ. Sci. Nat. Resour. 8(1): 99-104.

11. Akhter S, R Sen, S Akter, AHaque and S Noor 2012. Efficacy of Vermicompost to improve Soil Health, Yield and Nutrient Uptake of Cauliflower in Grey Terrace Soil of Bangladesh.Dyn. Soil Dyn. Plant.6: 103-109.

12. Atiyeh RM, CA Edward, NQ Arancon and JD Metzger 2002. The influence of humic acids derived from earthworm-processed organic wastes on plant growth. Bioresour. Technol. 84: 7-14.

13. Butler TJ, KJ Han, JP Muir, DC Weindorf and L Lastly 2008. Dairy manure compost effects on corn silage production and soil properties. Agron. J. 100: 1541-1545.

14. Azarmi R, MT Giglou and RD Taleshmikail2008. Influence of vermicompost on soil chemical and physical properties in tomato (Lycopersicum esculentum) field. Afr. J. Biotechnol. 7(14): 2397-2401.

15. Whalen JK, H Bensilm, Y Jiao and BK Sey 2008. Soil organic carbon and nitrogen pools as affected by compost applications to a sandy-loam soil in Quebec. Canadian. J. Soil Sci. 88: 443-450.

16. Renato $Y$ and ME Ferreira 2003. Organic matter fractions and soil fertility under the influence of liming, vermicompost and cattle manure. Af. J. Agric. Res. 60(3): 10-20.

17. Nardi S, F Morari, ABerti, M Tosoni and L Giardini 2004. Soil organic matter properties after 40 years of different use of organic and mineral fertilizers. Eur. J. Agron. 21: 357-367.

18. Choudhary GR and NL Jat2004.Response of coriander (Coriandrum sativum) to inorganic nitrogen, farm yard manure and biofertilizer. Indian J. Agric. Sci. 78: 761-763.

(Manuscript received on 11 November, 2018; revised on 10 December, 2018) 